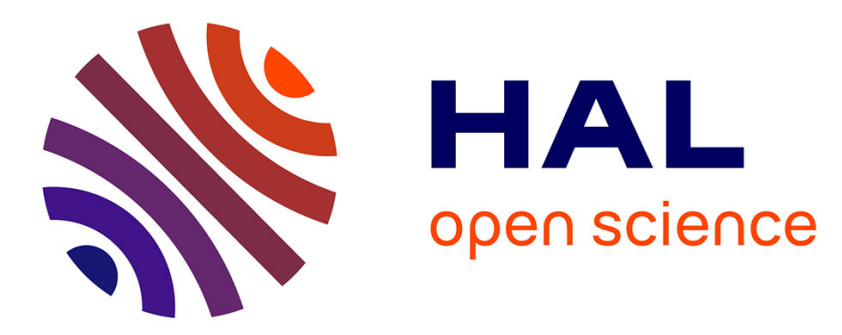

\title{
Sex-specific epigenetic impact of preconceptional maternal weight loss on foeto-placental development
}

Polina Panchenko, Mélanie Jouin, Luc Jouneau, Marion Lemaire, Claudine C. Junien, Anne Gabory

\section{- To cite this version:}

Polina Panchenko, Mélanie Jouin, Luc Jouneau, Marion Lemaire, Claudine C. Junien, et al.. Sexspecific epigenetic impact of preconceptional maternal weight loss on foeto-placental development. IFPA EPG 2014, Fetal placental-maternal crosstalk and pregnancy outcome, 2014, Paris, France. Elsevier, Placenta, 35 (9), 120 p., 2014, International Federation of Placenta Associations Meeting 2014. 10.1016/j.placenta.2014.06.121 . hal-02743611

\section{HAL Id: hal-02743611 https://hal.inrae.fr/hal-02743611}

Submitted on 3 Jun 2020

HAL is a multi-disciplinary open access archive for the deposit and dissemination of scientific research documents, whether they are published or not. The documents may come from teaching and research institutions in France or abroad, or from public or private research centers.
L'archive ouverte pluridisciplinaire HAL, est destinée au dépôt et à la diffusion de documents scientifiques de niveau recherche, publiés ou non, émanant des établissements d'enseignement et de recherche français ou étrangers, des laboratoires publics ou privés. 

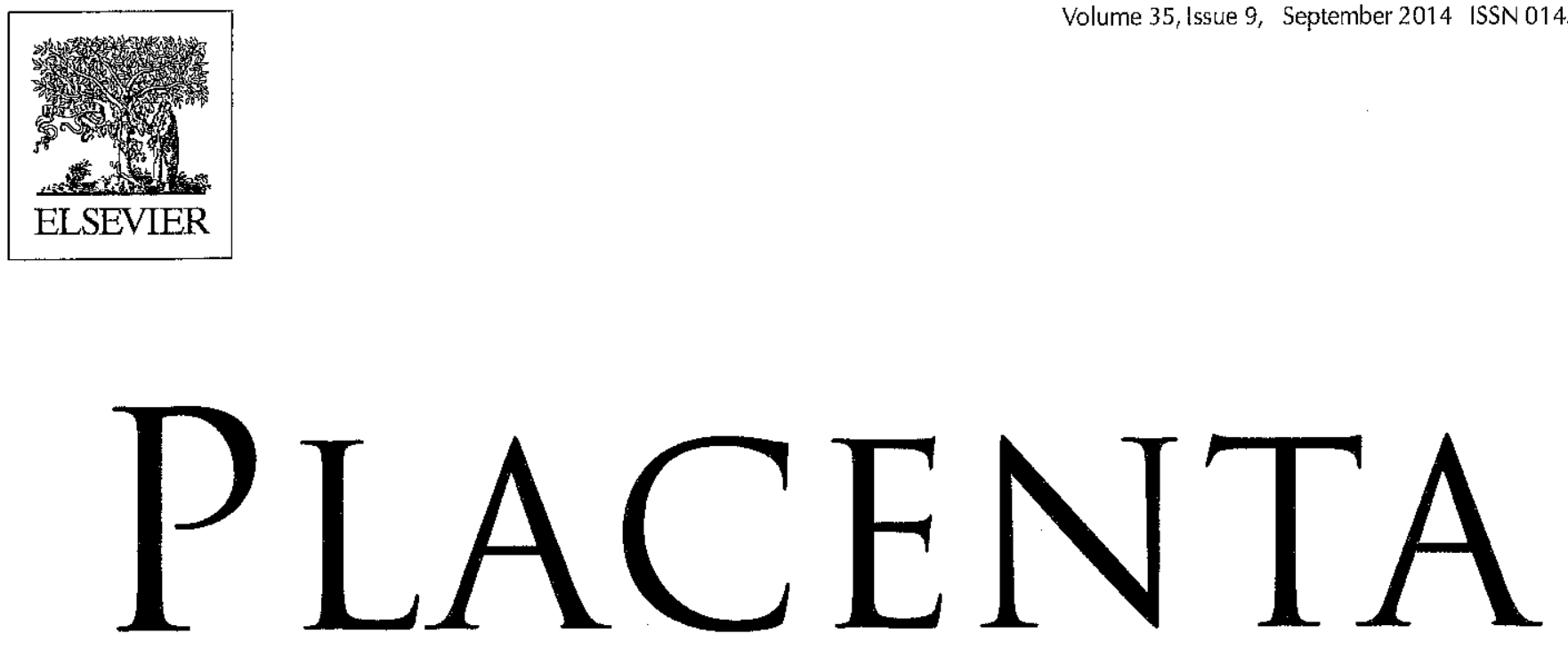

THE FRONTIER BETWEEN MOTHER AND FETUS

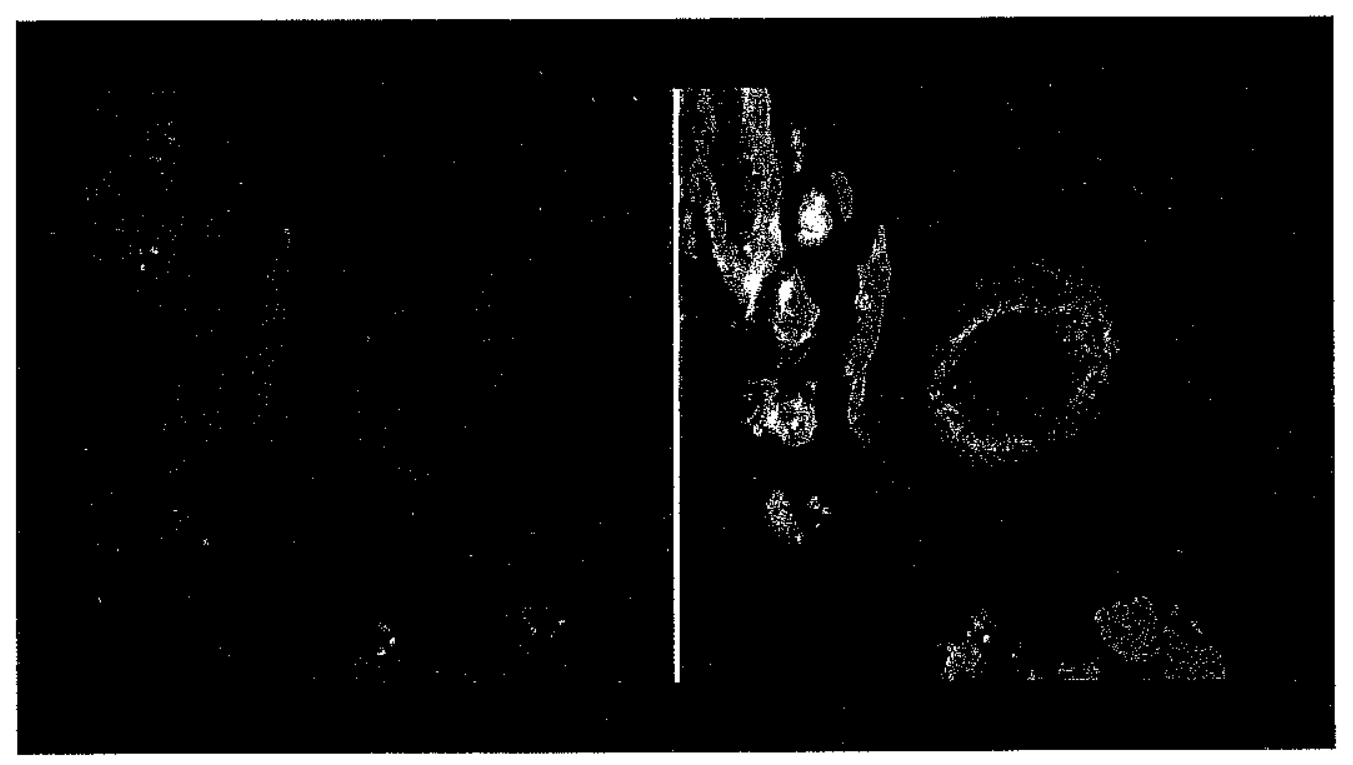




\section{IFPA EPG 2014}

September $9-12$

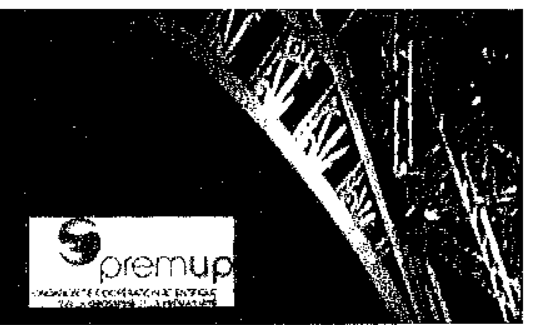

\section{Abstracts for the International Federation of Placenta Associations Meeting 2014}

Abstract Outline - IFPA 2014

Keynote Presentations
(KEY1 - KEY3)
(PL1.1 - PL5.2)
(TRA)
(SIFPAA)
(THAN)
(NIH)
(N1 - N5)
(N6 - N10)
(P1.1 - P1.163)
(P2.1 - P2.166)

Invited Speaker Presentationse

Elsevier Trophoblast Research Award

Senior IFPA Award Session 1

Gabor Than Award

NIH Sponsored lecture

New Investigator Oral Session 2

Poster session 1 
also measured using specific 5 -hmC or $5-m C$ immunoassays. The tissular distribution of $5-\mathrm{mC}$ and $5-\mathrm{hmC}$ was analyzed by immunostaining with 5 $\mathrm{mC}$ and 5 -hm $\mathrm{C}$ antibodies on paraffin sections.

Result: Our data provide the first overview of the distribution of 5-mC and 5-hmC during the development in bovine. We observed a lower level of 5$\mathrm{mC}$ in placental tissues compared with the embryonic and extraembryonic tissues from $30 \%$ to $90 \%$ of methylation (chorionic villi $<$ chorion $<$ liver $<$ heart < brain < amnion < allantois). Somatic cloning induced an increase of the methylation level in chorionic villi only in late pregnancy stages. However, only the mesenchymal cells of the chorionic villi were immunostained for $5-\mathrm{mC}$ and was involved in the methylation increase. In contrast, the $5 \mathrm{hm}-\mathrm{C}$ content and the staining were more stable between the different lineages, suggesting a role of this epigenetic mark in all lineages in bovine.

Conclusion: SCNT alters in a different manner the DNA methylation content in the cell lineages during the development.

\section{P1.85-N.}

SEX-SPECIFIC EPIGENETIC IMPACT OF PRECONCEPTIONAL MATERNAL WEIGHT LOSS ON FOETO-PLACENTAL DEVELOPMENT

Polina Panchenko ${ }^{a, b}$, Mélanie Jouin ", Luc Jouneau ${ }^{a}$,

Marion Lemaire ${ }^{\mathrm{a}}$, Claudine Junien ${ }^{\text {a.c }}$, Anne Gabory a aINRA, UMR1198 Biologie du Développement et Reproduction, Jouy-en-josas, France; ${ }^{b}$ University Pierre and Marie Curie (UPMC), Paris, France; ${ }^{C}$ Université de Versailles Saint-Quentin-en-Yvelines, Versailles, France

objectives: Whether the currently recommended preconceptional weight loss (WL) for obese women is beneficial/detrimental for fetal development and on the long term for the offspring has not been explored. Obesity, even if corrected before conception, and the WL processes could be "memorized" via epigenetic mechanisms perturbing expression of key developmental genes in placenta leading to altered fetal programming.

Methods: Female mice were fed a high-fat diet (HFD) for two months during the preconception period, leading to obesity and then a control diet (CD) for two months leading to a complete WL. In parallel, one group of mice was fed a HFD and another group a CD. We investigated the potentially sex-specific effects of maternal WL after diet-induced obesity on foeto-placental development and on gene expression of epigenetic machinery genes and key developmental genes in the placental labyrinth, junctional zone and foetal liver using Taqman custom array card, in male and female mice offspring.

Results: At E18.5, the weight of foetuses born to obese mothers fed a HFD was reduced ( $-12 \%$ for female, $-14 \%$ for male) compared to foetuses born to lean mothers fed a CD. Despite the normalization of maternal weight and metabolic phenotype, WL foetuses showed an intermediate value: $-3 \%$ for females and $-6 \%$ for males. There was no effect of maternal diet on placental weight. Interestingly placenta was sexually dimorphic, with male placentas $9 \%$ heavier than female ones. Fetus-to-placental-weight-ratioindex was decreased in foetuses from obese mothers but completely restored in foetuses from WL mothers.

Conclusion: Thus in comparison to offspring born to obese mothers, maternal preconceptional WL can improve to a great extent the neonatal phenotype of foetuses. This study should uncover potential relationships between early nutritional intervention, placental programming and susceptibility/resillience of adult offspring to an obesogenic environment.

\section{P1.86-N.}

HISTONE DEACETYLASE ACTIVITY AND NITRIC OXIDE CONTROL THE EXPRESSION OF ENOS AND ARGINASE-2 IN HUMAN UMBILICAL ARTERY ENDOTHELIUM IN INTRAUTERINE GROWTH RESTRICTION

Bernardo Krausea, Cherie Hernandeza, Daniela Schneidera, Paola

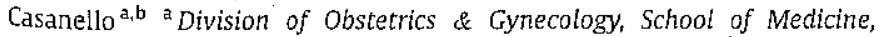
Pontificia Universidad Católica de Chile, Santiago, Chile; 'Division of Pediatrics, School of Medicine, Pontificia Universidad Católica de Chile, Santiago, Chile
Adult vascular dysfunction associated with intrauterine growth restriction (IUCR) is preceded by subtle vascular alterations. We reported that eNOS expression in endothelial cells derived from IUGR-placentae is influenced by DNA methylation, and reversed by silencing the DNA methylation machinery. However no reports show the effect of other epigenetic mechanisms on the expression of key genes of the NOS pathway such as arginase- 2 and eNOS.

Objective: To determine the effect of histone deacetylase (HDAC) activity and NO, reported as an HDAC inhibitor, on the expression of arginase- 2 and eNOS in IUGR-umbilical artery endothelium (HUAEC).

Methods: HUAEC were isolated by collagenase digestion from control and IUGR-umbilical artery and cultured to confluence. Cells were exposed to the HDAC inhibitor TSA $(0.1-10 \mu \mathrm{M}, 24 \mathrm{~h}$ ) with or without NOC-18 (NO donor, $100 \mu \mathrm{M}$ ) and L-NAME (NOS inhibitor, $100 \mu \mathrm{M}$ ). Chromatin accessibility at arginase-2 (ARG2) and eNOS (NOS3) promoter was analysed with EpiQ Chromatin Analysis kit (Biorad). Arginase-2 and eNOS mRNA levels were determined by qPCR.

Results: TSA up-regulated arginase-2 ( $\sim 4$ fold) and down-regulated eNOS expression in control and IUGR HUAEC. The effect of TSA on eNOS expression was not affected by NOC-18 and L-NAME. In control HUAEC the induction of arginase-2 by TSA was potentiated by NOC $-18(\sim 12$ fold $)$ and blocked by L-NAME, without changes in IUGR-HUAEC. In absence of TSA, NOC-18 induced arginase- 2 in control and IUGR HUAEC ( $\sim 3$ foid $)$, whilst LNAME reduced its expression only in control cells. Changes in arginase-2 expression were paralleled by changes in chromatin accessibility at ARG2 gene promoter.

Conclusion: HDAC activity has a differential effect on eNOS $(\uparrow)$ and arginase-2 $(\downarrow)$ expression in HUAEC. Apparently NO enhances chromatin accessibility at the arginase- 2 promoter, which can be potentiated by HDAC inhibition and this effect is higher in control compared with IUGR cells.
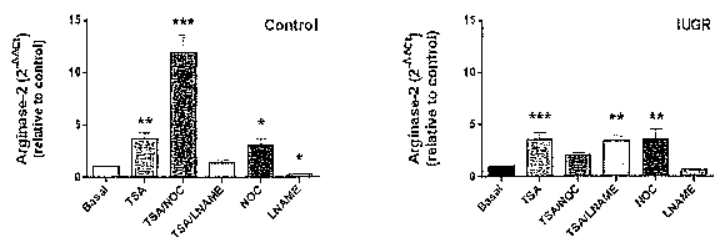

Funded by FONDECY $1120928 / 1$

Funded by FONDECYT 1120928/1130801

P1.87.

EFFECT OF MATERNAL BMI ON DNA METHYLATION AND HYDROXYMETHYLATION, A NOVEL EPIGENETIC MODIFICATION, IN THE PLACENTA

Kohzoh Mitsuya a, Ashley Parker a, Lu Liu ${ }^{b}$, Jianhua Ruan ${ }^{b}$, Leslie Myatt $^{a}$ a Center for Pregnancy and Newborn Research, Department of Obstetrics and Gynecology, University of Texas Health Science Center at San Antonio, Texas, USA; ${ }^{b}$ Department of Computer Science, University of Texas at San Antonio, Texas, USA

Introduction: The inflammatory or metabolic milieu of maternal obesity increases morbidity during pregnancy and programs offspring for development of disease in later life. The programming effect of the adverse intrauterine environment is transduced through the placenta. We have shown epigenetic modifications (DNA methylation, $5 \mathrm{mC}$ ) in the placenta of obese women compared to those of healthy weight. Recently a novel covalent modification 5-hydroxymethylcytosine (5hmc) has been demonstrated. The balance between $5 \mathrm{mC}$ (repressive) and $5 \mathrm{hmC}$ (permissive) in DNA may regulate placental gene expression and function.

Objective: We hypothesize that differences in cellular localization, overall amount and individual gene methylation/hydroxymethylation occur in placentas of obese vs healthy weight women. 